\title{
JAMUR LAGENIDIALES YANG DIISOLASI DARI LARVA KEPITING BAKAU, Scylla transquebarica
}

\author{
Des Roza") dan Fris Johnny*)
}

\begin{abstract}
ABSTRAK
Jamur merupakan salah satu penyakit utama pada larva kepiting bakau (Scylla transquebarica). Penelitian ini bertujuan untuk menemukan jamur yang patogen terhadap larva kepiting bakau. Tiga isolat jamur yaitu GSM-9710, GSM-9711, dan GSM-9712 diisolasi dari larva kepiting bakau stadia zoea pada awal Oktober 1997 di Balai Besar Riset Perikanan Budidaya Laut Gondol, Bali. Berdasarkan proses pembentukan dan pelepasan spora dari ketiga isolat tersebut maka isolat GSM-9710 diidentifikasi sebagai Haliphthoros milfordensis, isolat GSM9711 sebagai Halocrusticida harnanaensis dan isolat GSM-9712 sebagai Lagenidium scyllae. Kisaran suhu dan suhu optimum dari masing-masing isolat telah diketahui. Ketiga isolat jamur tersebut memerlukan jumlah mineral yang berbeda untuk pertumbuhannya. Di antara ketiga isolat jamur yang diuji patogenisitasnya terhadap larva kepiting bakau ternyata isolat GSM-9710 dan GSM-9711 lebih patogen dibanding GSM-9711. Ketiga isolat jamur ini baru pertama dilaporkan menginfeksi larva kepiting bakau ( $S$. transquebarica) di Indonesia.
\end{abstract}

ABSTRACT: Lagenidiales fungus collected from larvae of mangrove crab (Scylla transquebarica). By: Des Roza and Fris Johnny

Fungus is one of important diseases of mangrove crab (Scylla transquebarica) larvae, which mainly occurs at zoea stage. The main purpose of the research was to identify pathogenic fungus to the larvae of mangrove crab. In Gondol Research Institute for Mariculture, three fungal isolates (GSM-9710, GSM-9711, and GSM-9712) were collected from mangrove crab larvae in October 1997. From morphological observation, characters of each isolate identified were GSM-9710 as Haliphthoros milfordensis, GSM-9711 as Halocrusticida hamanaensis, and GSM-9712 as Lagenidium scyllae. Ranges of temperature and optimum temperature of each isolate were also already obtained. Based on artificial infection the among the three isolates, it showed that the isolates of GSM-9710 and GSM-9712 were most pathogen compared to GSM-9711. These fungus are the firstly reported infect to mangrove crab (S. transquebarica) larvae in Indonesia.

KEYWORDS: fungus, mangrove crab, Haliphthoros milfordensis, Halocrusticida hamanaensis, Lagenidium scyllae, Scylla transquebarica

\section{PENDAHULUAN}

Kendala utama yang dihadapi dalam usaha perbenihan krustase laut adalah adanya infeksi jamur dari kelompok Lagenidiales (Sparks, 1985; Nakamura \& Hatai, 1995) terutama Lagenidium sp. (Bland et al., 1976; Hatai, 1989; Nakamura et al., 1995; Roza et al., 1996; dan Roza et al., 1997); L. scyllae (Bian et al., 1979); L. myophyllum sp. nov.; L. callinectes Couch; (Hatai \& Lawhavinit, 1988; Nakamura \& Hatai, 1995); Haliphthoros sp. (Zafran et al., 1993); $H_{\text {. }}$ philippinensis (Hatai et al., 1992); H. milfordensis (Hatai et al., 1992; Nakamura \& Hatai, 1995); Halocrusticida hamanaensis (Hatai, 1989); $H$. okinawaensis (Nakamura \& Hatai, 1995); dan H. panulirata (Kitancharoen \& Hatai, 1995).

Di Balai Besar Riset Perikanan Budidaya Laut Gondol, Bali pada awal Oktober 1997 terjadi kematian massal larva kepiting bakau ( $S$. transquebarica) stadia zoea. Larva yang terinfeksi secara visual mengalami perubahan warna tubuh dari normal transparan menjadi keputih-putihan. Sedangkan pada tubuh larva yang sudah mati terlihat adanya bintik putih pada karapas bagian punggung. Dari pengamatan secara mikroskopis terhadap zoea tersebut, diketahui bahwa pada tubuhnya sudah dipenuhi oleh hifa dan adanya discharge tube yang memproduksi zoospora. Kematian larva kepiting bakau akibat infeksi jamur mencapai 100\%.

Berdasarkan permasalahan tersebut, maka perlu dilakukan penelitian untuk mengisolasi jenis jamur yang umum menginfeksi larva kepiting bakau di panti benih serta mengetahui tingkat patogenisitasnya. Hasil penelitian ini diharapkan dapat memajukan usaha perbenihan kepiting bakau di masa datang.

\footnotetext{
- Peneliti pada Balai Besar Riset Perikanan Budidaya Laut, Gondol
} 


\section{BAHAN DAN METODE}

\section{Isolasi dan Identifikasi}

Pada perbenihan kepiting bakau di Gondol, Bali, terjadi kematian massal larva pada stadia zoea-1. Terhadap zoea tersebut dilakukan pengamatan secara mikroskopis baik terhadap zoea yang mati maupun yang dalam kondisi lemah. Dari pengamatan terlihat bahwa pada tubuh zoea yang terinfeksi jamur sudah dipenuhi oleh hifa, maka terhadap zoea tersebut dilakukan isolasi jamur menggunakan media PYGSA (pepton 1,25 g; yeast ekstrak 1,25 g; glukose $3 \mathrm{~g}$; agar $12 \mathrm{~g}$ dalam $1 \mathrm{~L}$ air laut). Ke dalam cawan petri yang berisi $25 \mathrm{~mL}$ media PYGSA diinokulasikan zoea yang terinfeksi jamur, untuk menghambat terjadinya kontaminasi bakteri ditambahkan ampisilin dan streptomisin masing-masing sebanyak $500 \mathrm{mg}$. Kemudian diinkubasi pada suhu $25^{\circ} \mathrm{C}$ selama $48-72$ jam. Setelah itu miselia jamur yang aktif tumbuh tersebut dipindahkan ke media PYGSA baru dengan diameter $5,5 \mathrm{~mm}$ (Cork borer Nomor 2) untuk memperoleh isolat murni dan disimpan pada suhu $25^{\circ} \mathrm{C}$ untuk digunakan pada uji selanjutnya.

Untuk identifikasi secara morfologi, masing-masing isolat murni jamur yang diperoleh dikultur pada larutan PYGS (pepton 1,25 g; yeast ekstrak 1,25 g; glukosa $3 \mathrm{~g}$ dalam $1 \mathrm{~L}$ air laut). Caranya, ke dalam cawan petri yang berisi $25 \mathrm{~mL}$ larutan PYGS diinokulasikan miselia jamur yang aktif tumbuh pada media PYGSA dengan diameter 5,5 mm (Cork borer Nomor 2) dan diinkubasi pada suhu $25^{\circ} \mathrm{C}$ selama 72 jam. Setelah masa inkubasi akan terlihat adanya pertumbuhan miselia jamur, masing-masing miselia dicuci dalam air laut steril sebanyak dua kali. Kernudian miselia tersebut dipindahkan ke dalam cawan petri yang berisi $25 \mathrm{~mL}$ air laut steril dan diinkubasi pada suhu $25^{\circ} \mathrm{C}$ untuk pembentukan discharge tube dan zoospora. Dari pengamatan di bawah mikroskop akan terlihat jelas adanya zoospore germination, biasanya dalam kondisi kekurangan nutrien jamur akan terangsang membentuk dan melepas zoospora untuk sintasannya. Identifikasi jamur didasarkan pada proses pembentukan dan pelepasan zoospora.

\section{Pengaruh Suhu terhadap Pertumbuhan Vegetatif Jamur}

Penelitian ini bertujuan untuk mengetahui kisaran suhu dan suhu optirnal untuk pertumbuhan jamur. Pada penelitian ini dilakukan tujuh tingkat perlakuan suhu yakni $15^{\circ} \mathrm{C}, 20^{\circ} \mathrm{C}, 25^{\circ} \mathrm{C}, 30^{\circ} \mathrm{C}, 35^{\circ} \mathrm{C}, 40^{\circ} \mathrm{C}$, dan $45^{\circ} \mathrm{C}$ menggunakan media PYGSA. Miselia yang aktif tumbuh diinokulasikan di tengah media PYGSA dengan diameter $5,5 \mathrm{~mm}$ (Cork borer Nomor 2) untuk diinkubasi pada masing-masing perlakuan suhu tersebut. Pertumbuhan jamur diketahui dengan pengukuran diameter koloni jamur setiap hari selama seminggu pengamatan.

\section{Pengaruh Mineral terhadap Pertumbuhan Jamur}

Percobaan ini bertujuan untuk mengetahui kebutuhan mineral yaitu $\mathrm{NaCl}$ dan $\mathrm{KCl}$ untuk pertumbuhan jamur. Miselia jamur yang aktif tumbuh dengan diameter $5,5 \mathrm{~mm}$ (Cork borer Nomor 2) diinokulasikan ke dalam cawan petri yang berisi 30 mL PYGA (tidak menggunakan air laut tetapi akuades) yang telah ditambahkan tiga perlakuan konsentrasi $\mathrm{NaCl}$ dan $\mathrm{KCl}$ yaitu $1,0 \%$; $2,5 \%$; dan $5,0 \%$. Sedangkan sebagai kontrol adalah jamur yang diinokulasi pada media PYGSA dan PYGA (tanpa garam). Pengukuran diameter pertumbuhan jamur dilakukan setiap hari selama 7 hari pengamatan.

\section{Uji Tingkat Keganasan Isolat Jamur terhadap Larva Kepiting Bakau}

\section{Isolat GSM-9710}

Penelitian ini bertujuan untuk mengetahui tingkat keganasan isolat jamur GSM-9710 terhadap larva kepiting bakau. Rancangan yang digunakan dalam percobaan ini adalah acak lengkap dengan tiga perlakuan tingkat kepadatan zoospora dan tiap perlakuan tiga ulangan. Ke dalam dua belas botol kaca yang berisi $2 \mathrm{~L}$ air laut yang sudah ditreatmen (dengan sinar UV, ozonisasi, dan disaring dengan mikro filter $0,45 \mathrm{~mm}$ ) dimasukkan larva kepiting bakau stadia zoea-1 dengan kepadatan 25 ekor/mL. Kernudian ke dalam tiga botol yang dipilih secara acak diinokulasikan zoospora isolat GSM-9710 pada kepadatan $10^{2}$ zoosp. $/ \mathrm{mL}$, tiga botol pada kepadatan $10^{3}$ zoosp./mL dan tiga botol lagi kepadatannya $10^{4}$ zoosp./mL. Sedangkan sebagai kontrol adalah tiga botol lainnya tanpa inokulasi zoospora. Penelitian ini dilakukan selama 48 jam dan penghitungan total larva yang masih hidup dilakukan setelah 24 jam dan pada akhir penelitian. Larva diamati secara mikroskopis untuk mengetahui adanya hifa pada tubuh larva dan dilakukan isolasi ulang jamur.

\section{Isolat GSM-9711}

Penelitian ini bertujuan untuk mengetahui tingkat keganasan isolat jamur GSM-9711 terhadap larva kepiting bakau. Rancangan, perlakuan kepadatan zoospora isolat GSM-9711 dan pengamatan dalam penelitian ini sama dengan penelitian di atas.

\section{Isolat GSM-9712}

Penelitian ini bertujuan untuk mengetahui tingkat keganasan isolat jamur GSM-9712 terhadap larva kepiting bakau. Rancangan, perlakuan kepadatan 
zoospora isolat GSM-9712, cara kerja serta pengamatan sama dengan penelitian sebelumnya.

\section{HASIL DAN BAHASAN}

\section{Isolasi dan Identifikasi}

Telah diisolasi tiga isolat jamur yang menginfeksi larva kepiting bakau stadia zoea-1 (GSM-9710 dan GSM-9711) serta zoea-3 (GSM-9712) hasil penetasan di Laboratorium Patologi Balai Besar Riset Perikanan Budidaya Laut Gondol, Bali. Secara visual larva yang terinfeksi jamur terlihat adanya perubahan warna tubuh dari normal (transparan) menjadi keputih-putihan, pada karapas bagian punggung terlihat adanya bintik putih dan dari pengamatan secara mikroskopis terlihat bahwa pada tubuh larva tersebut sudah dipenuhi oleh hifa.

Secara morfologi isolat GSM-9710 mempunyai karakter antara lain warna koloni pada media PYGSA keputih-putihan dengan diameter 17,0-21,0 mm setelah lima hari inkubasi. Hifa bercabang tidak beraturan, tidak mempunyai septum, berbentuk batang yang licin dengan lebar 16-46 mm. Pembentukan protoplasma dalam hyphae terlihat dengan jelas pada media air laut. Perubahan bentuk protoplasma ke dalam sporangium tidak beraturan dengan bentuk dan ukurannya bervariasi yang memproduksi discharge tube. Banyak vakuola yang muncul dalam zoosporangium dan discharge tube yang keluar. Pembentukan zoospora terlihat setelah 10 jam pemindahan miselia ke dalam air laut dan berlangsung selama 5 hari. Pembentukan satu discharge tube biasanya dari cabang setiap zoosporangium (Hatai, 1989), maka isolat GSM-9710 diidentifikasi sebagai Haliphthoros milfordensis. Dua spesies Haliphthoros yang menjadi parasit pada hewan air yaitu $H$. milfordensis dan $H$. philippinensis (Tharp \& Bland, 1977; Hatai, 1989).

Isolat GSM-9711 memperlihatkan karakternya dengan koloni berwarna agak kuning dengan diameter 5,6-7,0 mm setelah tiga hari inkubasi pada suhu $25^{\circ} \mathrm{C}$ menggunakan media PYGSA. Hifa kuat, bercabang, dan mempunyai septum yang tipis, diameter hifa 12-40 mm. Hifa mempunyai ujung dengan diameter $150 \mathrm{~mm}$ yang berisi sitoplasma. Setiap sporangium membentuk septum dan beberapa cabang sebagai batas discharge tubes (tabung pelepasan). Discharge tube ini kadang-kadang berbentuk lurus atau berombak dengan ukuran 40-1.150 $\times$ 5-15 mm. Ukuran zoospora adalah 5,0-10,0 x 3,8-5,0 mm dengan flagela bercabang dua. Spora yang dikeluarkan diameternya 4,5-7,5 mm; berbentuk bola; dan kaku. Pada media air laut steril spora yang berenang akan berkembang membentuk filamen yang panjangnya $10-270 \mathrm{~mm}$. Ujung filamen melebar dan berkecambah menjadi tunas hifa dengan diameter 5-10 mm, vakuola tidak jelas dengan granula kecil dan licin. Dari karakter di atas dengan berpedoman pada Bian \& Egusa (1980) dan Hatai (1989) maka isolat GSM-9711 diidentifikasi sebagai Halocrusticida hamanaensis. Sedangkan isolat GSM-9712, bentuk hifa kuat, bercabang, mempunyai septum tipis. Pada kultur murni, hifa tumbuh agak seragam dengan diameter 7-17 mm dengan sitoplasma yang banyak sehingga tidak beraturan dan membesar sampai diameter besar dari $40 \mathrm{~mm}$. Pembentukan spora terjadi dari butir-butiran kecil yang kasar. Vesicle terbentuk pada akhir discharge tube dengan ukuran 37-5.000 x 4-10 mm dan diameternya $25-72,5 \mathrm{~mm}$ yang banyak mengandung protoplasma dengan diameter 22,5-65 mm. Zoospora adalah monoplanetik yang mempunyai dua flagela, bentuk, dan ukuran tidak beraturan seperti bola memanjang dengan ukuran $8-17,5 \times 7,5-15 \mathrm{~mm}$ yang membedakannya dengan protoplasma di dalam vesicle. Pelepasan zoospora berlangsung serentak dan cepat di mana satu persatu terus keluar dan berenang begitu vesicle terbuka. Zoospora yang keluar berbentuk bola dengan diameter 7,5-15 mm (rata-rata $10 \mathrm{~mm}$ ) mempunyai dinding yang tebal lebih besar dari 1,5 mm (Bian et al., 1979). Berdasarkan karakternya maka isolat GSM-9712 diidentifikasi sebagai Lagenidium scyllae. Sepintas karakter $L$. scyllae ini mirip dengan L. callinectes (Bland \& Amerson, 1973); hanya yang membedakannya adalah L. scyllae setelah 2-3 jam ditransfer ke dalam air laut akan memproduksi zoospora sedangkan $L$. callinectes perlu waktu yang lebih lama yaitu 12-15 jam. Selain itu pada $L$. scyllae kantong gelatin tidak kelihatan sedang L. callinectes terlihat jelas di mana di dalam vesicle terdapat protoplasma (Hatai, 1989; Nakamura \& Hatai, 1995). Karakter umum ketiga isolat jamur tersebut dapat dilihat pada Tabel 1.

Ketiga spesies dari kelompok Lagenidiales ini telah banyak dilaporkan sebagai patogen utama bagi organisme laut di antaranya yang menginfeksi beberapa krustase (Hatai, 1989); telur; dan larva kepiting bakau S. serrata (Kaji et al., 1991); kepiting laut $P$. pelagicus (Nakamura \& Hatai, 1995) bahkan Hatai (1982) menemukannya pada abalon, $H$. sieboldii. Di Gondol Haliphthoros dan Lagenidium sering ditemukan menginfeksi larva kepiting bakau, S. serrata (Zafran et al., 1993; Roza et al., 1996; Roza et al., 1997). Tetapi baru kali ini ditemukan Halocrusticida menginfeksi larva kepiting bakau terutama S. transquebarica.

\section{Pengaruh Suhu terhadap Pertumbuhan Vegetatif Jamur}

Dari penelitian ini terlihat bahwa isolat jamur GSM9710 dapat tumbuh pada kisaran suhu $15-30^{\circ} \mathrm{C}$ dan tumbuh optimum pada suhu $25^{\circ} \mathrm{C}$. Hasil ini sesuai 
Tabel 1. Perbedaan karakter ketiga isolat jamur GSM-9710, GSM-9711, dan GSM-9712 yang diisolasi dari larva kepiting bakau dibandingkan dengan Haliphthoros, Halocrusticida, dan Lagenidium menurut Hatai $(1989 ; 1993)$

Table 1. Differential characters of three fungal isolates GSM-9710, GSM-9711, and GSM-9712 isolated from mangrove crab larvae (Scylla transquebarica) in comparisons with those Haliphthoros, Halocrusticida, and Lagenidium by Hatai $(1989 ; 1993)$

\begin{tabular}{|c|c|c|c|c|c|c|}
\hline \multirow{2}{*}{$\begin{array}{l}\text { Karakteristik } \\
\text { Characteristics }\end{array}$} & \multicolumn{3}{|c|}{$\begin{array}{l}\text { Isolat yang diisolasi } \\
\text { (Present isolates) }\end{array}$} & \multicolumn{3}{|c|}{ Hatai $(1989,1993)$} \\
\hline & $\begin{array}{l}\text { GSM- } \\
9710\end{array}$ & $\begin{array}{l}\text { GSM- } \\
9711\end{array}$ & $\begin{array}{l}\text { GSM- } \\
9712\end{array}$ & Haliphthoros & Halocrusticida & Lagenidium \\
\hline $\begin{array}{l}\text { Diameter koloni } \\
\text { Colony diameter }(\mathrm{mm})^{*}\end{array}$ & $15-18$ & $5.6-7$ & $19-24$ & 17 & $6-5$ & $7-22$ \\
\hline $\begin{array}{l}\text { Formasi vesikel } \\
\text { Vesicle formation }\end{array}$ & $=$ & - & + & - & - & + \\
\hline $\begin{array}{l}\text { Tabung pelepasan } \\
\text { Discharge tube }\end{array}$ & long & short & long & long & short & long \\
\hline $\begin{array}{l}\text { Hifa halus } \\
\text { Slender hyphae }\end{array}$ & + & - & + & + & - & + \\
\hline $\begin{array}{l}\text { Cabang hifa } \\
\text { Hyphae branched }\end{array}$ & + & - & + & + & - & + \\
\hline $\begin{array}{l}\text { Fragmen hifa } \\
\text { Hyphae fragmented }\end{array}$ & + & - & - & + & - & - \\
\hline $\begin{array}{l}\text { Vakuola hifa } \\
\text { Hyphae vacuolated }\end{array}$ & + & - & $+/-$ & + & - & $+/-$ \\
\hline $\begin{array}{l}\text { Sekat hifa } \\
\text { Hyphae saccated }\end{array}$ & - & + & $+1-$ & - & + & $+/-$ \\
\hline $\begin{array}{l}\text { Disartikulasi } \\
\text { Disarticulation }\end{array}$ & - & - & - & - & 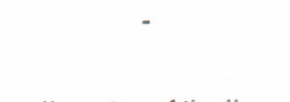 & - \\
\hline $\begin{array}{l}\text { Formasi zoospora } \\
\text { Zoospore formation }\end{array}$ & $\begin{array}{l}\text { small } \\
\text { parts }\end{array}$ & $\begin{array}{l}\text { all parts of } \\
\text { thallus }\end{array}$ & vesicle & small parts & all parts of thallus & vesicle \\
\hline $\begin{array}{l}\text { Diameter zoospora } \\
\text { yang dilepaskan }\end{array}$ & $5-7$ & $5-7$ & $8-10$ & $5-7$ & $5-7$ & $8-10$ \\
\hline $\begin{array}{l}\text { Encysted zoospore } \\
\text { diameter }(\mathrm{mm})\end{array}$ & & & & & & \\
\hline $\begin{array}{l}\text { Perkecambahan } \\
\text { seperti rambut } \\
\text { Hair like germination }\end{array}$ & + & + & - & + & + & - \\
\hline
\end{tabular}

Keterangan/Remarks: - = negatif/negative; $+=$ positif/positive

$=5$ hari setelah waktu inkubasi/after 5 days incubation time

dengan hasil penelitian Kaji et al. (1991); Hatai et al. (1992); Nakamura \& Hatai (1995). Isolat GSM-9711 tumbuh pada kisaran suhu $20-35^{\circ} \mathrm{C}$ dan tumbuh optimum pada suhu $30^{\circ} \mathrm{C}$ bahkan Nakamura \& Hatai (1995) juga menyatakan ini dari penelitiannya. Sedang isolat GSM-9712 dapat tumbuh pada suhu $15-40^{\circ} \mathrm{C}$ dengan suhu optimum $30^{\circ} \mathrm{C}$ sama dengan hasil penelitian Bian et al. (1979); Hatai et al. (1992); Nakamura \& Hatai (1995). Dari data ini diketahui bahwa isolat jamur ini lebih beradaptasi dengan lingkungan tropis. Data lengkap disajikan pada Tabel 2.

\section{Kebutuhan Mineral untuk Pertumbuhan Jamur}

Untuk menunjang pertumbuhannya jamur memerlukan mineral. Dari hasil penelitian diketahui bahwa masing-masing isolat jamur memerlukan jumlah mineral yang berbeda (Tabel 3). Isolat GSM9710 dapat tumbuh pada konsentrasi $\mathrm{NaCl} 2,5 \%$ dan $5 \%$ serta $\mathrm{KCl} 2,5 \%$ dan $5 \%$ sedang tumbuh optimum pada konsentrasi $2,5 \%$; tetapi pada konsentrasi $1 \%$ isolat jamur ini tidak tumbuh sama sekali. Sedang isolat GSM-9711 memperlihatkan hasil yang tidak jauh 
Tabel 2. Pengaruh suhu terhadap pertumbuhan isolat jamur GSM-9710, GSM-9711, dan GSM-9712 selama 7 hari masa inkubasi

Table 2. Effect of temperatures on growth of fungalisolates GSM-9710, GSM-9711, and GSM-9712 for 7 days incubation time

\begin{tabular}{cccc}
\hline \multirow{2}{*}{$\begin{array}{c}\text { Suhu }\left({ }^{\circ} \mathrm{C}\right) \\
\text { Temperature }\end{array}{ }^{\circ} \mathrm{C}$ C) } & \multicolumn{3}{c}{$\begin{array}{c}\text { Radius koloni }(\mathbf{m m}) \text { selama } 7 \text { hari masa inkubasi } \\
\text { Colony radius }(\mathbf{m m}) \text { for } 7\end{array}$ days incubation time } \\
\cline { 2 - 4 } & GSM-9710 & GSM-9711 & GSM-9712 \\
\hline 15 & 9.1 & 2.1 & 7.2 \\
20 & 21.5 & 8.2 & 16 \\
25 & 30 & 13.1 & 33 \\
30 & - & 14.6 & 55 \\
35 & - & - & 47 \\
40 & - & - & 32.4 \\
45 & - & - & - \\
\hline
\end{tabular}

Keterangan/Remark: - = tidak tumbuh/no growth

Tabel 3. Pengaruh $\mathrm{NaCl}$ dan $\mathrm{KCl}$ terhadap pertumbuhan isolat jamur GSM-9710, GSM-9711, dan GSM9712 selama 7 hari masa inkubasi

Table 3. Effect of $\mathrm{NaCl}$ and $\mathrm{KCl}$ on growth of fungal isolates GSM-9710, GSM-9711, and GSM-9712 for 7 days incubation time

\begin{tabular}{|c|c|c|c|}
\hline \multirow[t]{2}{*}{$\begin{array}{l}\text { Media } \\
\text { Medium }\end{array}$} & \multicolumn{3}{|c|}{$\begin{array}{l}\text { Radius koloni }(\mathrm{mm}) \text { selama } 7 \text { hari masa inkubasi } \\
\text { Colony radius }(\mathrm{mm}) \text { for } 7 \text { days incubation time }\end{array}$} \\
\hline & GSM-9710 & GSM-9711 & GSM-9712 \\
\hline PYGA $+1 \% \mathrm{NaCl}$ & - & 5.3 & 27 \\
\hline PYGA $+2.5 \% \mathrm{NaCl}$ & 19 & 10.5 & 22.3 \\
\hline PYGA + 5\% NaCl & 15.4 & - & 9.5 \\
\hline PYGA $+1 \% \mathrm{KCl}$ & - & - & 7 \\
\hline PYGA $+2.5 \% \mathrm{KCl}$ & 16.1 & 8.9 & 8.2 \\
\hline PYGA + 5\% KCl & 8 & - & - \\
\hline \multicolumn{4}{|l|}{ Control : } \\
\hline PYGA & - & - & 2.3 \\
\hline PYGSA & 28.3 & 12.8 & 31.1 \\
\hline
\end{tabular}

Keterangan/Remark: - = tidak tumbuh/no growth

berbeda di mana dapat tumbuh pada konsentrasi $\mathrm{NaCl}$ $2,5 \%$ dan $5 \%$ serta $\mathrm{KCl} 2,5 \%$ dan $5 \%$ juga tumbuh optimum pada konsentrasi $2,5 \%$. Tetapi isolat GSM9712 memperlihatkan hasil yang berbeda dari kedua isolat tersebut yaitu dapat tumbuh pada setiap konsentrasi $\mathrm{NaCl}$ baik 1\%; 2,5\%; maupun 5\% dan optimum pada konsentrasi $1 \%$. Sedang konsentrasi $\mathrm{KCl}$ yang dapat menunjang pertumbuhan isolat GSM9712 adalah $1 \%$ dan $2,5 \%$ dan konsentrasi optimum adalah 2,5\%. Kontrol pada media PYGA (tanpa garam) terlihat bahwa isolat jamur GSM-9710 dan GSM-9711 tidak tumbuh, tetapi isolat GSM-9712 dapat tumbuh walaupun pertumbuhannya lambat sekali. Hatai et al. (1992); Nakamura \& Hatai (1995) menyatakan bahwa jenis jamur ini tidak dapat tumbuh pada media tanpa garam karena jamur ini termasuk golongan jamur yang berasal dari laut. Sedangkan kontrol pada media PYGSA ketiganya tumbuh dengan baik. Dari data ini dapat disimpulkan bahwa kebutuhan mineral pada ketiga isolat jamur tersebut tidak sama, hal ini erat hubungannya dengan spesies masing-masing.

\section{Patogenisitas Isolat Jamur terhadap Larva Kepiting Bakau}

\section{Isolat Jamur GSM-9710}

Dari penelitian diketahui bahwa perlakuan infeksi zoospora GSM-9710 pada kepadatan $10^{4}$ zoosp. $/ \mathrm{mL}$ setelah 24 jam sudah mengakibatkan kematian $75 \%$. 
Setelah dilakukan pengamatan terhadap larva yang mengalami kematian tersebut ternyata pada seluruh bagian tubuhnya telah penuh dengan hifa dan setelah 48 jam infeksi larva mati total. Pada perlakuan infeksi zoospora $10^{3}$ dan $10^{2}$ zoosp. $/ \mathrm{mL}$ setelah 24 jam infeksi tidak memperlihatkan angka kematian yang drastis yakni hanya $15 \%$ dan $12 \%$, akan tetapi setelah 48 jam terlihat peningkatan mortalitas masing-masing menjadi $47 \%$ dan 33\%. Hasil pengamatan terhadap larva kepiting bakau yang mati ditemukan hifa yang memenuhi seluruh permukaan tubuhnya, ini berhubungan erat dengan hasil isolasi ulang di mana diisolasi jamur yang sama dengan isolat GSM-9710 dari larva yang mati tersebut. Sedangkan pada kontrol ada juga larva yang mati sebesar $5 \%$ setelah 24 jam dan $11 \%$ setelah 48 jam, tetapi tidak terlihat adanya hifa baik dari pengamatan di bawah mikroskop maupun dari reisolasi. Hasil lengkap disajikan pada Tabel 4. kontrol tidak terlihat adanya infeksi jamur, hal ini juga terbukti dari reisolasi.

\section{Isolat GSM-9712}

Hasil yang diperoleh pada penelitian ini tidak begitu berbeda dari percobaan sebelumnya. Pada perlakuan infeksi zoospora isolat jamur GSM-9712 dengan kepadatan $10^{4}$ zoosp./mL, setelah 24 jam menyebabkan kematian bagi larva kepiting bakau sebesar $39 \%$ dan setelah 48 jam sebesar $82,0 \%$. Sedangkan pada perlakuan kepadatan $10^{3}$ zoosp. $/ \mathrm{mL}$ mencapai 24\% (24 jam) dan 62,5\% (48 jam); tetapi pada perlakuan infeksi $10^{2}$ zoosp. $/ \mathrm{mL}$ terlihat angka kematian larva sebesar 18\% (24 jam) dan 50\% (48 jam). Dari pengamatan di bawah mikroskop terhadap larva yang mati tidak satu pun larva yang pada tubuhnya bebas hifa. Pada kontrol, kematian larva yang terjadi tidak begitu besar hanya 5\% (24 jam) dan $8 \%$

Tabel 4. Patogenisitas isolat GSM-9710, GSM-9711, dan GSM-9712 terhadap larva kepiting bakau (Scylla transquebarica) stadia zoea-1 selama 24 dan 48 jam pengamatan

Table 4. Pathogenicity of isolates GSM-9710, GSM-9711, and GSM-9712 on larvae of mangrove crab (Scylla transquebarica) at zoea-1 stage for 24 and 48 hours observation

\begin{tabular}{|c|c|c|c|c|c|c|c|c|}
\hline \multirow{3}{*}{$\begin{array}{l}\text { Isolat } \\
\text { Isolates }\end{array}$} & \multicolumn{8}{|c|}{$\begin{array}{l}\text { Rata-rata mortalitas larvae yang diinfeksi dengan zoospora } \\
\text { Mortality average of larvae (\%) infected by zoospora (zoosp. } / \mathrm{mL} \text { ) }\end{array}$} \\
\hline & \multicolumn{4}{|c|}{24 hours observation } & \multicolumn{4}{|c|}{48 hours observation } \\
\hline & $10^{4}$ & $10^{3}$ & $10^{2}$ & Control & $10^{4}$ & $10^{3}$ & $10^{2}$ & Control \\
\hline GSM-9710 & 75.0 & 15.0 & 12.0 & 5.0 & 100.0 & 47.0 & 33.0 & 11.0 \\
\hline GSM-9711 & 45.0 & 12.5 & 7.5 & 7.5 & 100.0 & 43.0 & 35.0 & 15.0 \\
\hline GSM-9712 & 39.0 & 24.0 & 18.0 & 5.0 & 82.0 & 62.5 & 50.0 & 8.0 \\
\hline
\end{tabular}

\section{Isolat Jamur GSM-9711}

Pada perlakuan infeksi zoospora dengan kepadatan $10^{4}$ zoosp./mL, ternyata setelah 24 jam sudah berdampak kematian terhadap larva kepiting bakau sebesar $45 \%$ dan mati total setelah 48 jam (Tabel 4). Pengamatan terhadap larva yang mengalami kematian tersebut memperlihatkan bahwa hifa jamur sudah tumbuh memenuhi permukaan tubuhnya. Pada perlakuan kepadatan yang lebih rendah yaitu $10^{3}$ dan $10^{2}$ zoosp./mL tidak begitu membahayakan terhadap larva kepiting bakau di mana tingkat kematiannya hanya sebesar $12,5 \%$ dan $7,5 \%$ setelah 24 jam dan setelah 48 jam mengalami peningkatan mortalitas masing-masing menjadi $43 \%$ dan $35 \%$. Dibanding kontrol, dengan tingkat kematian setelah 24 jam hanya $7,5 \%$ tetapi setelah 48 jam menjadi 15\%. Dari pengamatan terhadap larva yang mati pada perlakuan terlihat adanya hifa pada tubuh larva tersebut tetapi
(48 jam) dan setelah diamati terlihat tidak ada hifa pada tubuhnya dan diduga kematian bukan akibat infeksi jamur. Untuk data lengkap dapat dilihat pada Tabel 4.

Dibandingkan pada perlakuan isolat GSM-9710 dan GSM-9711 terlihat bahwa kedua isolat ini lebih patogen terhadap larva kepiting bakau dibandingkan isolat GSM-9712. Hal ini terlihat dari pengamatan secara mikroskopis terhadap larva yang mati di mana terlihat tubuhnya sudah hancur akibat perkembangan hyphae jamur tersebut. Tetapi frekuensi serangan kedua isolat jamur ini tidak sesering infeksi isolat GSM-9712, ini terbukti dari jarangnya jamur ini diisolasi dari telur maupun larva kepiting bakau.

Dari data di atas dapat disimpulkan bahwa ketiga genera jamur tersebut yaitu Lagenidium, Haliphthoros, dan Halocrusticida merupakan patogen utama bagi kepiting bakau (Kaji et al., 1991; Hamasaki \& Hatai, 
1993) bahkan juga mematikan bagi kepiting laut (Kitancharoen \& Hatai, 1995).

Larva kepiting bakau sangat rentan terhadap penyakit baik infeksi jamur maupun bakteri terutama Vibrio harveyi di mana pada kepadatan infeksi $10^{3}$ cfu/mL sudah menyebabkan kematian massal setelah 24 jam (Roza et al., 1993; Roza, 1997).

\section{KESIMPULAN}

Telah berhasil diisolasi tiga isolat jamur yaitu GSM9710, GSM-9711, dan GSM-9712 dari larva kepiting bakau stadia zoea. Dari karakter secara mortologi maka isolat GSM-9710 diidentifikasi sebagai Haliphthoros milfordensis, GSM-9711 sebagai Halocrusticida hamanaensis, dan GSM-9712 sebagai Lagenidium scyllae. Sedangkan tingkat patogenisitas ketiga genera Lagenidiales ini tidak sama, isolat GSM9710 dan GSM-9711 lebih patogen dibandingkan isolat GSM-9712.

\section{DAFTAR PUSTAKA}

Bian, B.Z., K. Hatai, G. Lio-Po, and S. Egusa. 1979. Studies on the fungal diseases in crustaceans. I. Lagenidium scyllae sp. nov. isolated from cultivated ova and larvae of mangrove crab (Scylla serrata). Trans. Mycol. Soc. Japan 20: 115-124.

Bian, B.Z. and S. Egusa. 1980. Atkinsiella hamaensis sp. nov. isolated from cultivated ova of the mangrove crab Scylla serrata (Forskal). J. Fish Dis. 3: 373-385.

Bland, C.E. and H.V. Amerson. 1973. Observations on Lagenidium callinectes : isolation and sporangial development. Mycologia 65: 310-320.

Bland, C.E., D.G. Ruch, B.R. Salser, and D.V. Lightner. 1976. Chemical control of the Lagenidium, a fungal pathogen of marine crustacea. A University of North Caroline, Sea Grant Program Publication. UNC-SG76-02.

Hamasaki, K. and K. Hatai. 1993. Experimental infection in the eggs and larvae of the swimming crab Portunus trituberculatus and the mud crab Scylla serrata with seven fungal strains belonging to Lagenidiales. Nippon Suisan Gakkaishi 59: 1059-1066. (In Japanese).

Hatai, K. 1982. On the fungus Haliphthoros milfordensis isolated from temporarily held abalone (Haliotis sieboldii). Fish Pathol. 17: 199-204. (In Japanese).

Hatai, K. 1989. Fungal pathogens and parasites of aquatic animals. In Austin, B. and B. Austin (Eds.), Methods for Microbiological Examination of Fish and Shellfish. Ellis Horwood Limited, England. p. 250258.
Hatai, K., W. Rhoobunjongde, and S. Wada. 1992. Haliphthoros milfordensis isolated from gills of juvenile kuruma prawn (Penaeus japonicus) with black gill disease. Trans. mycol. Soc. Japan 33: 185-192.

Hatai, K. 1993. Fungal diseases in various crustaceans. Prosiding Simposium Perikanan Indonesia I Pusat Penelitian dan Pengembangan Perikanan 18:17-27.

Nakamura, K. and K. Hatai. 1995. Three species of Lagenidiales isolated from the eggs and zoeae of the marine crab Portunus pelagicus. Mycoscience 36: 87-95.

Nakamura, K., M. Nakamura, K. Hatai, and Zafran. 1995. Lagenidium infection in eggs and larvae of mangrove crab (Scylla serrata) produced in Indonesia. Mycoscience 36: 399-404.

Kaji, S., M. Kanematsu, N. Tezuka, H. Fushimi, and K. Hatai. 1991. Effects of formalin bath for Haliphthoros infection on ova and larvae of the mangrove crab Scylla serrata. Nippon Suisan Gakkaishi 57: 51-55. (In Japanese).

Kitancharoen, N. and K. Hatai. 1995. A marine oomycete Atkinsiella panulirata sp. nov. from philozoma of spiny lobster, Panulirus japonicus. Mycoscience 36: 97104.

Roza, D., Zafran, A. Parenrengi, dan T. Ahmad. 1993. Studi pendahuluan penyakit kunang-kunang pada larva kepiting bakau, Scylla serrata. J. Penel. Budidaya Pantai 9(3):119-124.

Roza, D., Fris Johnny, dan Yunus. 1996. Uji coba pemantaatan bakteri untuk menghambat perkembangan jamur Lagenidium sp. pada larva kepiting bakau (Scylla serrata). Seminar Nasional Mikrobiologi Lingkungan II, Lembaga limu Pengetahuan Indonesia. Bogor, 9-10 Oktober 1996. $10 \mathrm{pp}$.

Roza, D. 1997. Tingkat keganasan dan penanggulangan bakteri Vibrio bercahaya pada larva kepiting bakau (Scylla serrata) Prosiding Seminar Nasional Biologi $X V$, Perhimpunan Biologi Indonesia, Bandar Lampung II: 501-504.

Roza, D., F. Johnny, Zafran, Yunus, dan K. Yuasa. 1997. Studi pendahuluan tentang pengaruh $\mathrm{pH}$ terhadap Lagenidium sp. pada larva kepiting bakau (Scylla serrata Forskal). Simposium Perikanan Indonesia II, Pusat Penelitian dan Pengembangan Perikanan. Ujung Pandang, 3-4 Desember 1997. 11 pp.

Sparks, A.K. 1985. Synopsis of Invertebrate Pathology. Elsevier, Amsterdam. p. 205-237.

Tharp, T.P. and Bland, C.E. 1977. Biology and host range of Haliphthoros milfordensis. Can. J. Bot. 55: 2.9362.944 .

Zafran, D. Roza, dan A. Parenrengi. 1993. Karakterisitik dan penanggulangan jamur Lagenidium sp. pada larva kepiting bakau, Scylla serrata. J. Penel. Budidaya Pantai 9(4):29-39. 